\title{
Kaizen Felsefesi ile Toplam Kalite Yönetiminin Verimlilik ve Maliyet Üzerine Etkisi
}

\author{
Effect of Kaizen Philosopy and Total Quality Management on Productivity and Cost
}

\author{
Harun ÖĞÜNÇ \\ Öğr. Gör., Mehmet Akif Ersoy Üniversitesi, Bucak Hikmet Tolunay MYO (ogunc@mehmetakif.edu.tr) \\ Ercüment DOĞRU \\ Yrd. Doç.Dr., Mehmet Akif Ersoy Üniversitesi, Ağlasun MYO (ercumentdogru@mehmetakif.edu.tr)
}

\begin{abstract}
ÖZET
Anahtar kelimeler:

Toplam Kalite

Yönetimi

Kaizen

Verimlilik

Günümüzde giderek artan rekabet nedeniyle işletmeler hem müşteri beklentilerini karşılamak hem de üretim süreçlerini daha etkin kullanarak hatasız mamuller üretmek için kaliteye daha fazla önem vermektedirler. Ayrıca, üretim süreçlerinde sürekli olarak iyileştirme çalışmaları yapılması da bir gereklilik haline gelmiştir. Üretimde kullanılan girdi ile üretim süreci sonunda elde edilen çıktının oranlanması olarak ifade edilen verimlilik, işletmelerin maliyetlerindeki azalmayla da yakından ilgilidir. Bunun yanında kaliteye yönelik çalışmaların ve iş süreçlerindeki küçük iyileştirmeler olarak ifade edilen kaizenlerin de maliyetler ve verimlilik üzerinde olumlu etkiye sahip olması beklenmektedir.

Bu kapsamda, çalışmada kaizen felsefesi ve toplam kalite yönetimi yaklaşımlarının verimlilik artışına etkileri üzerinde durulmuştur. Kaizen maliyetleme ve toplam kalite yönetimi sistemlerini uygulayarak verimlilik artışına ilişkin olumlu sonuçlar elde eden işletmeler üzerinden kaizen, toplam kalite yönetimi ve verimlilik artışı ile maliyetler arasındaki ilişki incelenmiştir.
\end{abstract}

\section{ABSTRACT}

Keywords:

Total Quality

Management

Kaizen

Productivity

Today, due to increasing competition, businesses attach more importance to quality both to meet customer expectations and to produce error-free products more efficiently using production processes. In addition, it has become a necessity to constantly improve the production processes. Efficiency, expressed as the ratio of the input used in production to the output obtained at the end of the production process, is closely related to the decrease in the costs of the enterprises. On the other hand, it is also expected that quality-oriented work and kaizenes which are expressed as minor improvements in the work process will have positive effects on costs and productivity.

In this context, the effects of kaizen philosophy and total quality management approaches on productivity increase are emphasized. Through the application of Kaizen costing and total quality management systems, the relationship between kaizen, total quality management and efficiency increase and costs have been examined through the firms that have achieved positive results regarding productivity increase. 


\section{GÍRIŞ}

İşletmelerin rekabet edebilir hale gelmesinde veya mevcut durumunu geliştirebilmesinde hedef maliyetleme, değer mühendisliği, tam zamanında üretim, yalın üretim, toplam kalite yönetimi ve kaizen maliyetleme gibi birçok farklı sistemden faydalandığı görülmektedir. Her sistemin yaklaşımı farklı olmakla birlikte nihai amaç, işletmenin verimliliğine, sürekliliğine ve kârlılığına katkı sağlamaktır. Bu durum, maliyetlerin doğru şekilde belirlenmesini amaçlayan faaliyet tabanlı maliyetleme için olduğu kadar, sıfır stok ve sıfır israf anlayışındaki tam zamanında üretim için de geçerlidir.

Ürünlerinde kaliteyi ön planda tutan işletmelerin, müşteri beklentilerini karşılayabilmek için sürekli bir yenilik içerisinde bulunmaları ve bunu gerçekleştirirken de maliyetlerini kabul edilebilir seviyede tutmaları gerekmektedir. Bu nedenle maliyet yönetimi çalışmalarına önem verilmesi ve bu çalışmalarda birden çok yöntemden faydalanılması gerekmektedir.

$\mathrm{Bu}$ çalı̧̧mada kaizen maliyetleme ile toplam kalite yönetimini uygulamanın verimlilik artışına katkıları ve maliyet üzerine etkileri ele alınmıştır.

\section{KAİZEN VE TOPLAM KALITTE YÖNETIMİ}

\subsection{Kaizen}

İyi yönde ve sürekli gelişmeyi ifade eden kaizen teriminden yola çıkan kaizen felsefesinde temel çıkış noktası, hiçbir şeyin mükemmel olmadığı ve her zaman daha iyisinin gerçekleştirilebileceğidir (Karakaya, 2004:586). Değişime odaklanan kaizen felsefesinde, hayatın tüm alanında küçük adımlarla sürekli iyileştirme amaçlanmaktadır. Bu iyileştirmeler evde, işte, özel yaşamda, kısaca her yerde gerçekleştirilebilmektedir. Söz konusu iyileştirme faaliyetinin işyerinde uygulanması amaçlanıyorsa üst yönetim dâhil olmak üzere hem yönetici hem işçinin katılımı sağlanmalıdır. Bu felsefede esas önemli olan, mevcut durumla yetinmeyip hep daha iyiye ulaşmayı amaçlamaktır. Çünkü “mevcut durumla yetinmek kaizen'in baş düşmanıdır" (Çetinay, 2013:2).

Üretim sürecinde ortaya çıkan maliyetlerin düşürülmesinde önemli bir rol üstlenen kaizen maliyetleme yönteminde, sonuçların iyileştirilebilmesi için süreçlerin iyileştirilmesi gerektiği üzerinde durulmaktadır. Çünkü süreç uygun şartlara sahip değilse, beklenen sonuca ulaşmak da mümkün olmayacaktır. Sürece ilişkin dikkate alınması gereken disiplin, zamanı iyi kullanma, becerilerin geliştirilmesi, paylaşma ve etkin katılım, moral ve iletişim gibi kriterler üzerinde özellikle durulmalıdır (Çetinay, 2013:11; Yükçü, 2000:26-31).

\subsubsection{Kaizen ve Yenilik Arasındaki Fark}

Kaizen felsefesinde, yeniliklerin küçük adımlar halinde uygulanması esastır. Bunun gerçekleştirilebilmesi için, çalışanlara öncelik vererek tüm personelin katılımının sağlanması ve kademeli bir ilerleme sayesinde kalıcı, sürekli ve düzenli bir yapının oluşturulması oldukça önemlidir. Büyük ve ani şekilde gerçekleşen yenilik ise, teknoloji ve parayı öncelikli olarak üst sıraya yerleştirmektedir. Ani gerçekleşen yenilik nedeniyle sınırlı düzeyde katılım sağlanmakta ve koruyucu özelliği olmadığı için bu yenilik, eski makine ve ekipmanların hurdaya ayrılarak yerine yeni makine ve ekipmanların alınması ile sonuçlanmaktadır (Çetinay, 2013:7). Buradan hareketle yenilik ve kaizen arasındaki farklılıkların aşağıdaki gibi gösterilmesi mümkündür: 
Tablo 1. Kaizen ile Yenilik Arasındaki Farklılıklar

\begin{tabular}{|l|l|}
\hline Yenilik & Kaizen \\
\hline Kısa vadelidir & Uzun vadelidir \\
\hline Büyük adımlar atılmasını gerektirir & Küçük adımların sabırla atılması gerekir \\
\hline Sınırlı sayıda kişi ile uygulanır & Tüm personel sürece dâhil edilir \\
\hline Teknoloji ön plandadır & İnsan ön plandadır \\
\hline Büyük yatırım gerektirir & Mevcut imkânlara ek olarak küçük yatırım gerektirir \\
\hline Yeni personel istihdamı gerektirir & Mevcut personelle uygulanır \\
\hline Yeni finansal kaynak gerektirir & Mevcut kaynaklar yeterlidir \\
\hline
\end{tabular}

Kaynak: Merih ESKİN, Uran Tiryakioğlu, H.Deha Yüceil, (2011). Sanayide Sürekli Gelişme için:“Kaizen”. İstanbul Sanayi Odası, İkinci Baskı, İstanbul, s.11.

\subsubsection{Sanayi ve Ürün Açısından Kaizen Yönetimi}

Bir süreçler bütünü olan sanayide malzeme, insan gücü, makine, yönetim ve finans bu süreçlerin girdilerini oluştururken, sürecin sonucunu değerlendirecek olan müşteriler; kalite, maliyet ve teslim süresini dikkate almaktadır. Kaizen çalışmaları kalitenin artmasına, maliyetlerin düşmesine ve teslim süresinin kısalmasına katkıda bulunmaktadır. Sanayi açısından üretim metodunda, süreçlerinde ve ürün özelliklerinde küçük değişiklikler yapılarak çıktılarda iyileşmeyi sağlayan kaizen; mevcut bütçe, donanım ve makineyle yapılmaktadır (Eskin vd., 2011:8-10).

Hedef kâra ulaşmayı amaçlayan işletme için, üretimi gerçekleştirilen her parçanın maliyeti, kaizen maliyet açısından düşürülmesi gereken bir veri olmaktadır. Yeni ürün geliştirme aşamasında, ürünün temel fonksiyonlarında yapılacak değişikliklerle maliyetleri düşürmeyi amaçlayan değer mühendisliği ile mevcut ürünün tasarım aşamasında yapılacak değişiklikleri içeren değer analizi çalışmalarının her ikisi de, kaizen maliyetlemede faydalanılması gereken yöntemlerdir (Monden ve Hamada, 1991:25-26).

Üretim sürecinde bir problem mevcutsa, bunu fark eden ilk kişi, o makineyi kullanandır. Dolayısıyla problemin çözümünde ve durumun iyileştirilmesinde işgörenin doğrudan etkisi olmaktadır. Ayrıca, kaizen çalışmalarında toplam maliyet hedeflerinden ziyade birim düzeyinde sabit ve değişken maliyetleri azaltma hedeflerinin koyulması, çalışanlar açısından bu hedeflerin daha anlaşılır hale gelmesini sağlayacaktır. Bunun yanında kaizen çalışmasının işletme yönetimince benimsenmesi ve aşağıdaki unsurlara özellikle dikkat edilmesi ile daha etkin bir kaizen süreci ortaya çıkacaktır (Monden ve Hamada, 1991:27, Eskin vd., 2011:7-47):

- Kaizen çalışmalarında liderlik rolü üstlenecek bir yönetim veya bu rolü yapması için görevlendirilmiş gönüllü personel bulunmalidir.

- Kaizen her ne kadar birey bazlı bir iyileştirme olarak görülse de uygulanabilir hale gelmesi için ekip çalışması gereklidir.

- Problemlerin farkına varılabilmesi için personelin farkındalığının oluşması, bunun için de kaizen eğitimine tabi tutulması gereklidir.

- Kaizen çalışmalarının etkinliğini artırmak için elde edilen kaizenler toplantılarla ve afiş̧lerle tüm personele duyurulmalıdır.

- Kaizen çalışmaları için personelin motive edilmesi, teşvik edilmesi, kaizen oluşturan personelin ödüllendirilmesi veya takdir edilmesi sağlanmalıdır. 
$\mathrm{Bu}$ yöntemin başarısı için, maliyet düşürme çalışmalarına ilişkin toplantıların tesis, kısım, bölüm ve süreç gibi farklı düzeyler itibariyle gerçekleştirilmesi ve kaizen maliyet hedeflerinin bu düzeylere tahsis edilmesi önem arz etmektedir (Monden ve Hamada, 1991:27).

\subsubsection{Kaizen Süreci ve Uygulama Yöntemleri}

Kaizen, süreci esas alan bir yaklaşım olması nedeniyle bir sorun varsa bunun personelden değil süreçten kaynaklandığını ve sürecin iyileştirilmesi gerektiğini ileri sürmektedir. Kaizen çalışmaları gerçekleştirilirken sorunun tanımlanması, çözüm için fikir üretilmesi ve uygulama aşamalarından oluşan temel üç adım karşımıza çıkmaktadır (Eskin vd., 2011:20-25).

Sorunun tanımlanması aşamasında bir işin mevcut durumdan daha iyi nasıl yapılabileceği düşüncesiyle hareket edilmelidir. Sorunlar tespit edilirken aşağıdaki yollar kullanılabilir:

- Yanlış giden bir durumun fark edilmesi: Örneğin makineden olağandışı bir ses gelmesi,

- Görünmeyen sorunların tespit edilmesi: Örneğin bir iş sürecinde gereksiz hareket sonucu oluşan israfın tespit edilmesi,

- Anahtar kelimelerin kullanılması: Örneğin “neden böyle?” "daha iyi nasıl olabilir?" gibi sorular veya "tekrar, çok zaman alıyor, kontrol" gibi ifadelerin üzerine gidilmesi.

İkinci adım olan fikir üretme aşamasında "eleme, azaltma ve değiştirme" işlemleri esas alınmaktadır. Yani gereksiz olanlar elenmekte, gereğinden fazla olanlar azaltılmakta veya uygun olmayanlar değiştirilmektedir. Bu aşamada yapılabilecekler aşağıdaki gibi sıralanabilir:

Tablo 2. Fikir Üretme Aşamasında Yapılabilecekler

\begin{tabular}{|c|c|}
\hline Eleme yolları & $\begin{array}{l}\text {-Kullanımdan kaldırma } \\
\text {-Durdurma } \\
\text {-Çıkarma }\end{array}$ \\
\hline Azaltma yolları & $\begin{array}{l}\text {-Basitleştirme } \\
\text {-Merkezileştirme } \\
\text {-Standartlaştırma } \\
\text {-Bütünleştirme }\end{array}$ \\
\hline Değiştirme yolları & $\begin{array}{l}\text {-Alternatifler bulma } \\
\text {-Takas etme } \\
\text {-Dönüştürme } \\
\text {-Çeşitlendirme } \\
\text {-Ayrıştırma }\end{array}$ \\
\hline
\end{tabular}

Kaynak: Eskin vd., age, s:22

Problem belirlenip buna ilişkin fikirler üretildikten sonra üçüncü adım olan uygulama hayata geçirilebilecektir. Elde edilen faydanın bir rapor haline getirilmesi ve çalışanlarla paylaşılması halinde motivasyon kazanmaları sağlanacaktır. Bunun yanında kaizen çalışmalarında rolü olanların ödüllendirilmeleri ve takdir edilmeleri de kaizen sisteminin sürekliliği için gereklidir.

Kaizen sürecinde problemin çözümü için genellikle pareto diyagramları, 5N1K yöntemi, kontrol tabloları ve saçılma diyagramları gibi yardımcı araçlar kullanılmaktadır. Bunun yanında, problemin büyüklüğüne ve karmaşıklığına göre 
yöntem farklılı̆̆ da ortaya çıkmaktadır. "Önce-sonra kaizen” genellikle çalışanların önerileri ile ortaya çıkmaktadır ve kısa sürede sonuç alınabilmektedir. Bu yöntemde çalışanların etkin katılımı sağlandığı için moral ve motivasyon artışı ortaya çıkmakta ve çalışanları düşünmeye yöneltmektedir. "Odaklanmış kaizen" ise farklı bölümlerden katılımcılarla problemin esas sebebinin bulunması için çalışıldığı, daha karmaşık bir yöntemdir ve aşağıda verilen on aşamadan oluşmaktadır (Çetinay, 2013:26-29):

Tablo 3. Odaklanmış Kaizen Aşamaları

\begin{tabular}{|l|l|}
\hline & 1- Konunun seçimi \\
& 2-Hedefin belirlenmesi \\
Planlama & $\begin{array}{l}\text { 3-Çözüm için ekibin atanması } \\
\text { 4-Mevcut durumun tespit edilmesi } \\
\text { 5-Projenin planlanması } \\
\text { 6-Analiz }\end{array}$ \\
\hline Uygulama & 7-Planın uygulanması \\
\hline Kontrol Etme & 8-Uygulamanın denetlenmesi \\
\hline \multirow{2}{*}{ Önlem Alma } & $\begin{array}{l}\text { 9-Standartlaştırma çalışmalarının yapılması } \\
\text { 10-Standartların yaygınlaştırılması }\end{array}$ \\
\hline
\end{tabular}

Kaynak: Halil Çetinay, "Kaizen El Kitabı - Sürekli İyileştirme”, Treem Kaizen El Kitabl, Treem Eğitim Danışmanlık, 2013, http://www.treem.com.tr/kaizenelkitabi.pdf, Erişim: 20.09.2016, s.27.

Kaizen maliyetlemeyi uygulayabilmek için, öncelikle, hem fiziksel hem de düşünsel açıdan işletmenin hazır halde olması gerekmektedir. Esas olan, sorunları önleyici bir yapının benimsenmesidir; ancak mevcut sorunların ortadan kaldırılması için de gerektiğinde reaktif hareket edilmelidir (Macpherson vd., 2015:6). Kaizen çalışmalarında aşağıdaki sürecin titizlikle uygulanması, beklenen sonucun elde edilmesinde önemli bir rol oynamaktadır (Çetinay, 2013:20-22).

- Kaizen eğitimlerinin, öncelikle üst ve orta yönetim ile amirler tarafindan alınması gerekmektedir.

- Eğitim danışmanı, yönetime yol haritası oluşturma konusunda yardımcı olmalıdır.

- Doğru verilerin elde edilmesi için veri toplama sistemi oluşturulmalıdır.

- Standart iş tanımlarındaki eksiklikler tamamlanmalıdır.

- Ölçümler yapılmış ve kayıp alanları belirlenmiş olmalıdır.

- Mümkünse çalışanlara kaizen eğitiminin yönetici tarafından verilmesi, en azından yöneticinin eğitim çalışmalarına katılması gerekmektedir.

\subsubsection{Kaizen ve $5 S$}

Düzenli bir çalışma ortamı isteniyorsa, "5S Kaizen" yönteminin uygulanması, oldukça faydalı olacaktır. Bu teknikte, çalışanların kullanacağı tüm aletler, olması gereken yerde ve düzenli bir şekilde durmaktadır. Çalışmayı olumsuz etkileyebilecek unsurlar ortadan kaldırılmış, artık malzemeler ayrı ayrı kutularda biriktirilmiştir. Bahsi geçen 5S, Japonca sözcüklerden oluşmaktadır ve anlamları aşağıda verilmiştir (Eskin vd., 2011:33): 


\begin{tabular}{|l|l|}
\hline Sei-ri & Toparlanma \\
\hline Sei-ton & Düzenli olma \\
\hline Sei-so & Temizlik \\
\hline Sei-ke-tsu & Standardizasyon \\
\hline Shi-tsu-ke & Disiplin \\
\hline
\end{tabular}

Toparlanma aşamasında öncelikle çalışma ortamının fotoğrafı çekilerek değişim sonrası ile öncesi arasındaki farklılık daha gözle görülür hale getirilebilir. Çalışma ortamında bulunan makine ve takımların üzerine ayın ilk günü kırmızı bir etiket yapıştırılarak ay içinde kullanılanların üzerindeki etiketin sökülmesi ve ay sonunda üzerinde hala etiket bulunanların yerinden kaldırılması, toparlanma için kullanılabilecek önemli bir çalışmadır. Düzenli olma aşaması, işlerin aksamadan devam edebilmesi için oldukça önemlidir. Örneğin montajı yapılacak bir makine için gerekli olan anahtar yerinde bulunmuyorsa montaj süresi uzayacaktır. Bu kapsamda atölyelerde sıklıkla görülen şekilde aletlerin yerlerinin çizili hale getirilmesi, düzenli olma ilkesini yansıtmaktadır. Çalışma ortamında olumsuz durumlarla karşılaşmamak için bir diğer önemli unsur temizliktir. Üretim sürecinde ortaya çıkan talaşın etrafa saçılmadan kolaylıkla depolanmasını sağlamak için düzenek oluşturulması, iş kaybının önüne geçecektir. Standardizasyon, ideal durumun tanımlanması ve neyin nasıl olması gerektiğinin açık şekilde belirtilmesini kapsamaktadır. Bu sayede mevcut durum ile ideal durumun karşılaştırılması mümkün hale gelmektedir. Disiplin ise, yapılan iyileştirmelerin sürdürülebilirliğini ve kalıcı bir hale gelmesini sağlamaktadır (Eskin vd., 2011:33-39).

Kaizen felsefesinde standartlar hayati bir öneme sahiptir; çünkü standartların olmadığı bir yerde ne ile uğraşıldığı, mevcut durumun analizi, kayıplar, dalgalanmalar, değişikliklerin tespiti gibi daha birçok konuda belirsizlikler hâkim olacaktır. Ancak burada dikkat çeken husus, kaizen'in standartları değişim için bir basamak olarak kullanmasıdır (Çetinay, 2013:4-5).

5S aşamalarından toparlanma, düzenli olma ve temizlik; işletme ortamının çalışmaya uygun hale getirilmesiyle ilgili terimlerken standardizasyon terimi, söz konusu ortamdaki uygun durumun "nasıl olması" gerektiğini belirten yönlendirmelerden oluşmaktadır. Disiplin ise standartların hayata geçirilmesi için çalışanları motive edici bir yapıya sahiptir. Tüm bu işlemlerin gerçekleştirilmesi halinde işletme içerisinde aksaklığa meydan verebilecek durumların önüne geçilmiş olmaktadır.

\subsection{Kalite ve Toplam Kalite Yönetimi}

\subsubsection{Kalite}

Günümüz koşullarında denetlenmesi gereken bir unsur olmaktan çıkıp, tasarlanması gereken bir değişken haline gelen kalite, tüketici beklentilerinin karşılanmasıyla doğru orantılı bir yapıya sahiptir (Acar, 2005:85). Dolayısıyla müşteri beklentilerini dikkate almadan üretilen mamul, üretici açısından kaliteli olarak algılansa da tüketiciyi tatmin etmiyorsa, üretim için fazladan yapılan harcamanın ötesine geçemeyecektir.

Kaliteli üretim, sektörde kalıcı bir yere sahip olmak isteyen işletmeler için satış sonrasını da kapsayacak bir şekilde tüketicinin memnuniyetini gerektirmektedir. 2016 yılında Samsung Note 7 modelinde yaşanan şarj sorunu ve sonrasında tüketicilerden bu ürünün toplanarak yerine yenisinin verilmesi hem kalitesiz üretimin oluşturacağ yüksek maliyetin boyutunu, hem de müşteri memnuniyeti sağlamak için firmanın gösterdiği çabayı ortaya koymaktadır.

Kalitenin önemi günümüzde daha anlaşılır hale geldikçe, kaliteye ilişkin sorunlar da gözle görülür hale gelmiş, dolayısıyla tasarımcı, mühendis, girişimci, yönetici, üretici ve tüketici de dâhil olmak üzere çok sayıda tarafı ilgilendiren bir unsur olarak karşımıza çıkmıştır (Özbirecikli, 2001:82). Ancak kalite, işçilerin yaptıklarından daha çok, üst yönetimin kararları ve yaptıklarının bir sonucu olarak ortaya çıkmaktadır. Çünkü bir işin nasıl yapılması gerektiğini ve süreçte çalışanların nasıl hareket etmeleri gerektiğini belirleyenler, çalışanların eğitimlerini, alet ve ekipmanların seçilmesi ve kullanıma sunulmasını 
sağlayanlar yönetimdekilerdir ve bu kapsamda kalite yönetimi sayesinde işletmelerin elde edebileceği faydaların aşağıdaki gibi sıralanması mümkündür (Geçikli, 1999:37, Alkan, 2001:185):

- İsrafin önlenmesi,

- Kalitenin artırılması,

- İşlem zamanında kısalma,

- Maliyetlerde düşüş,

- Motivasyon ve verimlilik artış1,

- Sürekli iyileşme ve gelişme.

\subsubsection{Toplam Kalite Yönetimi}

Toplam kalite yönetimi (TKY), müşteri memnuniyetinin maksimum düzeye ulaşması için müşteri ve çalışanların beklentilerinin belirlenmesi ve bu beklentilerinin ötesinde karşılanması hususunda tüm çalışanların sorumlu olduğu, iş ve süreçlerde ekip çalışmasının desteklendiği ve süreç kontrolünün sürekli kontrol altında tutulduğu, sürekli gelişimin hedeflendiği bir yönetim şeklidir (Basık, 2012:360).

TKY; örgüt içerisinde kalitenin geliştirilmesi, korunması ve iyileştirilmesi amacıyla üretimden pazarlamaya kadar tüm departmanlarda ekonomik amaçların gerçekleştirilmesinde etkili bir sistem olarak karşımıza çıkmaktadır (Karcıoğlu, 2001:11). Özellikle esnek üretim sistemlerinin yaygınlaşması ve müşteri tatminine verilen önemin artması gibi nedenlerle işletmelerin toplam kalite yönetimini daha fazla uygular hale geldikleri görülmektedir. Bu sistemde üretim sonrası kontrol ve düzeltme yerine tüm kayıp ve israfin en baştan engellenmesi amaçlanmaktadır (Hacırüstemoğlu ve Şakrak, 2002:14).

\subsubsection{Toplam Kalite Yönetiminin İlkeleri}

Toplam kalite yönetiminde arzulanan sonuçlara ulaşılabilmesi için özellikle dikkat edilmesi gereken ilkeler aşağıda sıralanmıştır (Karcıoğlu ve Biçer, 2013:4):

- Önceliği insana vermek,

- Müşteri odaklı bir yapıyı benimsemek,

- Çalışanların kalite eğitimlerini önemsemek,

- Ekip çalışmasını benimsemek,

- Üst yönetimin liderlik yapması,

- İstatistiki verilerin öneminin kavranmas1,

- Sürekli gelişme ve iyileştirmelerin gerekliliğinin benimsenmesi.

Yukarıdaki ilkeler, esasında, insan odaklı bir yönetim tarzının önemini vurgulamaktadır. Üst yönetimin liderliğinde insan öncelikli, müşteri odaklı ve kalite konusunda eğitilmiş personelin ekip halinde çalışmasının gerekliliğini ifade eden ilkeler de bu düşünceyi doğrulamaktadır.

Kaliteli üretim gerçekleştirebilmek için çok yönlü veri akışının bulunması, sürecin daha hızlı ve aksamadan işlemesine yardımcı olmaktadır. Bu nedenle mevcut hata oranları, üretim kesintilerinin sıklık düzeyi, hatasız bir şekilde tamamlanan ürün miktarı gibi işletme içi kaynakların yanında müşteriler tarafından bildirilen hatalı ürün miktarı ve söz konusu hataların sıklığı gibi işletme dışı bilgi kaynakları da kalite geliştirme ve kalitenin sürdürülebilmesinde oldukça önemlidir (Hacırüstemoğlu ve Şakrak, 2002:15). Bunun yanında sıfır hata ile üretim yapmayı ilke edinen işletmelerin kalite yönetimine yönelik çabaları, işletmenin kalıcılığı açısından büyük öneme sahiptir. Kalite yönetimi sayesinde israf önlenecek, kalite artışı sağlanacak, işlem zamanında kısalma ve maliyetlerde düşüş sağlanacaktır. Ayrıca elde edilen başarılı sonuçlarla çalışanların ve üst yönetimin moral ve verimliliğinde ortaya çıkan artış sayesinde sürekli iyileşme ve gelişmenin önü açılacaktır (Alkan, 2001:185-186).

\subsubsection{Kalite Maliyetleri ve Unsurları}

Kalite maliyetleri, "hataları önleme, tanımlama, onarma, düşük kaliteyi yükseltme faaliyetlerinin maliyetiyle, kayıp üretimden ve düşük kalite nedeniyle kaybedilmiş satışlardan doğan alternatif maliyetlerin toplamıdır" (Basık, 2012:363). 
Dolayısıyla kalite artışının işletmeye bir bedelinin olacağı göz önünde tutularak, harcamaların dengeli bir şekilde yapılması gerekmektedir. Bunun yanında müşteri beklentilerini karşılamayan bir ürünün işletmeye iade edilmesinin de bir maliyet unsuru olduğu unutulmamalıdır. Söz konusu olumsuzluklarla karşılaşmamak için işletmenin bütün olarak kalite maliyetlerine odaklanması gerekmektedir (Kaya, 2013:144).

Sistemsel hatalardan kaynaklanan stok kayıpları, ürün kayıpları, hatalı ürünler, üretimdeki gecikmeler, hurda, düzeltme işlemleri, geç teslimat, garanti ile ilgili şikayetler ve müşterinin iyi niyetinin kaybedilmesi gibi olumsuzluklar kalite maliyetlerini oluşturmaktadır (Acar, 2005:87). Bunun bir sonucu olarak kalite maliyetlerinin müşteri kaybı, satış kaybı ve kâr kaybı açısından değerlendirilmesi ve optimum bir denge içerisinde kalite üzerinde odaklanılması gerekmektedir; çünkü müşterinin değer vermediği derecede bir kalite için yapılan harcama, kârlılı̆̆ 1 olumsuz etkilediği gibi, kalitesiz ürün de müşteri ve satı̧̧ kaybına neden olacaktır (Kaya, 2013:145).

Kalite maliyetlerinin israfı önleyerek maliyetlerin düşürülmesi, toplam kalite yönetiminin uygulanması ve mamul yerine işletmenin tümüne odaklanmasını içeren üç temel ilkesi bulunmaktadır. Bunlar; nihai ürüne değer katmayan unsurların elenmesi, bir işlemin bir kerede ve doğru bir şekilde yapılması ve sürekli geliştirme faaliyetlerinin uygulanmasıdır. Kalite maliyetleri; mevcut durumun tespiti, işletmenin durumu dikkate alınarak yeni hedeflerin belirlenmesi ve bu hedeflere ulaşmak için yapılması gerekenlerin planlanması aşamasında yol gösterici bir özelliğe sahiptir. Söz konusu kalite maliyetlerinin kullanım alanları aşağıdaki gibi sıralanabilir (Hacırüstemoğlu ve Şakrak, 2002:142-143):

- Kalite faaliyetlerinin ölçülmesi,

- Maliyeti yüksek faaliyetlerin belirlenmesi,

- Kalite kontrol personelinin verimli ve etkin şekilde kullanılmasına yönelik organizasyonun yapılması,

- Müşteri ilişkilerinin düzenlenmesi,

- Yan sanayi ile ilişkilerin düzenlenmesi,

- Kaliteye yönelik çalışmalar için bütçenin belirlenmesi,

- Çalışanın neyi neden yaptığına yönelik bilince sahip olması.

\subsubsection{Kalite Maliyetlerinin Türleri}

Kalite maliyetleri; önleme ve değerleme maliyetlerinden oluşan "uygunluk maliyetleri” ile içsel başarısızlık ve dışsal başarısızlık maliyetlerinden oluşan "uygunsuzluk maliyetleri”" şeklinde bir ayrıma tabi tutulabilir. Düşük kalitenin önüne geçebilmek için üretimden önce alınan tedbirler önleme maliyetlerini oluşturmaktadır. Değerleme maliyetleri ise üretim aşamasında standartlara uygunluğun ve performansın ölçülmesinde öne çıkmaktadır. Bu kapsamda kalite planlaması, eğitimi, denetimi, yönetimi ile satın alma ve pazarlama gibi önleyici maliyetlerin ortaya çıkması muhtemeldir. Satın alınan girdilerin muayene maliyetleri ile üretim sürecinde ve üretim sonrasında kabul edilebilirlik testleri gibi maliyet unsurları ise değerleme maliyetini oluşturmaktadır. Uygun olmayan ürün veya hizmetlerle ilgili sevkiyat veya hizmet sunumu öncesinde ortaya çıkan tamir ve yeniden işleme gibi maliyetler, iç başarısızlık maliyetlerini oluştururken; sevkiyat veya hizmet sunumu sonrası oluşan garanti, servis ve tazminat gibi maliyetler ise, dış başarısızlık maliyetlerini oluşturmaktadır. $\mathrm{Bu}$ kapsamda, kalite maliyetlerinin aşağıdaki gibi sıralanması mümkündür (Hacırüstemoğlu ve Şakrak, 2002:144-146):

Tablo 4. Kalite Maliyeti Çeşitleri

\begin{tabular}{|l|l|l|}
\hline \multirow{2}{*}{ Kalite Maliyetleri } & Alt Unsurlar & Örnek \\
\hline \multirow{2}{*}{ Uygunluk Maliyetleri } & Önleme Maliyetleri & Kalite planlaması \\
\cline { 2 - 3 } & Değerleme Maliyetleri & Girdilerin muayene maliyetleri \\
\hline \multirow{2}{*}{ Uygunsuzluk Maliyetleri } & İç Başarısızlık Maliyetleri & Sunum öncesi tamir \\
\cline { 2 - 3 } & Diş Başarısılık Maliyetleri & Sunum sonrası garanti \\
\hline
\end{tabular}


Yukarıda sayılan kalite maliyetlerinin ortaya çıkış zamanları ve kapsamları ise aşağıdaki şekilde gösterilmiştir.

Tablo 5. Ortaya Çıkış Zamanı ve Kapsamına Göre Kalite Maliyetleri

\begin{tabular}{|c|c|c|c|}
\hline Üretim Öncesi & Üretim Süreci & Üretim Sonrası & Satış Sonrası \\
\hline \multicolumn{3}{|l|}{ Önleme Maliyeti } & \\
\hline & \multicolumn{2}{|c|}{ Değerleme Maliyetleri } & \\
\hline & & İçsel Başarısızlık Maliyetleri & \\
\hline & & & Dışsal Başarısızlık Maliyetleri \\
\hline
\end{tabular}

Kaynak: Feryâl Orhon Basık, Rekabet Stratejisinde Maliyet Yönetimi, Türkmen Kitabevi, İstanbul, 2012, s.364.

Yukarıdaki şekil incelendiğinde önleme maliyetlerinin üretim öncesini ve üretim sürecini kapsadığı; değerleme maliyetinin ise üretim süreci ve üretim sonrasında ortaya çıktığı görülmektedir. Bunun yanında içsel başarısızlık maliyetleri, üretim sürecinin ortalarında başlayıp üretim sonrasını kapsamasına rağmen, dışsal başarısızlık maliyetleri sadece satış sonrasında ortaya çıkmaktadır.

İhtiyaca ve gerekliliklere uygunluk olarak ifade edilen kalitenin eksikliğinde de bir maliyet ortaya çıkmaktadır ve bu kalitesizlik maliyetinin önüne geçilebilmesi için tasarımdan itibaren tüm sürecin iyileştirilmesi ve sıfır hata ile üretimin gerçekleştirilmesi amaçlanmalıdır (Kutlu, 2008:91).

\section{KAİZEN VE KALITE ARTIŞI İLE VERIMLİLIK-MALİYET İLIŞKİSi}

Verimlilik, bir üretim sürecinde belirli çıktıların elde edilmesi için gereken girdilerin minimum maliyet ve miktarda kullanılmasıyla ortaya çıkmaktadır. Verimlilik tespitinde, işletmenin iş süreçlerini ne şekilde yerine getirdiği önemli bir husustur. Bir üretim faaliyetinin işgücüne dayalı olarak yerine getirilmesi veya robotlara dayalı sermaye yoğun bir şekilde gerçekleştirilmesi gerektiğinin belirlenmesi ekonomik verimliliği ifade ederken; ürüne değer katmayan faaliyetlerin ortadan kaldırılarak israfın önlenmesi teknik verimlilik kapsamına girmektedir. Dolayısıyla verimlilik sadece işgücü ve makineler açısından değil, faaliyetlerin ürüne kattığı değer açısından da değerlendirilmelidir. Verimliliğini artırmak isteyen işletmelerin öncelikle bir durum değerlendirmesi yapması ve bunun için de aşağıdaki gibi bazı kriterler belirlemesi gerekmektedir (Basık, 2012:171-174):

- İşletmenin geçmiş dönemlerdeki verimlilik sonuçları,

- İşletmenin departmanlarında ortaya çıkan verimlilik ölçüleri,

- Aynı sektördeki diğer firmaların verimlilik ölçüleri,

- Tepe yönetimin hedeflediği verimlilik ölçüsü.

Söz konusu kriterler, işletmenin ve rakiplerin geçmiş ve mevcut durumlarının karşılaştııılması sayesinde gelecek hedeflerinin şekillenmesine yardımcı olacaktır.

İşletmelerin hayatını sürdürebilmesi için, kaliteli üretime ve kalitenin sürekli iyileştirilmesi üzerine odaklanması ve bunu gerçekleştirirken de maliyetlerin talebi etkilemeyecek şekilde ayarlanması gerektiği genel kabul gören hususlardır. Söz konusu amaca uygun şekilde işletmenin kaynaklarını verimli ve etkin bir şekilde kullanması hem maliyet artışını engelleyecek hem de kaliteli ürün üzerindeki maliyet baskısını ortadan kaldıracaktır (Hacırüstemoğlu ve Şakrak, 2002:15). 
Malzeme, iş̧ilik, makine-donanım, enerji ve zamanın doğru kullanımıyla elde edilen verimlilik artışı, maliyetlerde düşüşe yol açacaktır. Dolayısıyla kalite yönetimi sayesinde israfın önlenmesi, işlem zamanının kısalması ve maliyetlerin düşmesi sağlanmakta; sonrasında ise sürekli iyileşme ve gelişme çalışmalarıyla kalite, motivasyon ve verimlilik artışı elde edilmektedir (Alkan, 2001:185, Altınok ve Saçl1, 2009:71).

İşletmelerin olağan süreçlerinde ortaya çıkabilecek hataların tespit edilmesi ve bu hataların tahlil edilmesi uzun vadeli çalışmalarla sağlanmakta olup sonrasında söz konusu hataların tekrar edilmemesi hedeflenmektedir. Burada sürekli iyileştirme çalışmalarının önemi yadsınamaz. İşletmenin tüm fonksiyonlarının tam katılımı sayesinde sürekli iyileştirme çalışmaları, hata oluşumunu minimum düzeye indirecek, kalite artışıla birlikte maliyetlerde azalma, kârlılık ve verimlilik artışı ile müş̧eri memnuniyetinde artış sağlanacaktır (http://www.muhasebetr.com/yazarlarimiz/yilmazvelioglu/008/).

Günümüz koşullarında kalite, maliyet ve zaman hem müşteri açısından hem de satıcı açısından önemli bir yere sahiptir; ancak burada kalitenin önemi daha fazla ortaya çıkmaktadır. Çünkü zamandan tasarruf sağlama ve maliyetleri azaltma faktöründen dolayı kalitenin maliyet ve zamanı etkileyen bir yapısı bulunmaktadır. Bu kapsamda kalitenin artırılmasıyla ortaya çıkabilecek başlıca faydaların aşağıdaki gibi sıralanması mümkündür (Karcıoğlu, 2001:18, Akgün, 2005:32):

- Hurda, atık, bozuk ürün miktarında azalma,

- Satış iadesi ve satış sonrası bakım maliyetlerinde azalma,

- Müşteri taleplerinin zamanında karşılanması,

- Firma değerinin artmas1.

Kalite ile verimlilik arasında sıkı bir ilişki bulunmaktadır. Öyle ki, kaliteli girdi sayesinde en düşük seviyede israf ortaya çıkmaktadır ve dolayısıyla kaliteli mamul için temel koşulların büyük bölümü sağlanmış olmaktadır. Bunun yanında üretim sürecine getirilen yenilikler ve mamuldeki değişiklikler, daha az yeniden işleme gerek duyulan ve daha kaliteli mamuller üretilmesini sağlayacaktır. Bu kapsamda işletmedeki faaliyet ve süreçlerin sürekli iyileştirilmesi, kaynak israfının önlenmesi ve değer katmayan faaliyetlerden kaçınılması, maliyetlerin düşmesine olanak sağlayacaktır. Dolayısıyla faaliyetler için elektrik enerjisi, sermaye, işçilik, malzeme gibi girdiler ile makine hazırlık ve ayar sayısı, kontrol saatleri gibi çıktılar dikkate alınarak faaliyet verimlilik analizlerinin yapılması ve faaliyetlerin birleşimiyle ortaya çıkan süreçlerin verimlilik analizinin yapılması gerekecektir (Basık, 2012:172-181).

Kalitenin günümüz rekabet koşullarında önemli; ama tek başına yetersiz bir unsur olduğu göz ardı edilmemelidir. Kalite artışından maliyetlerin olumsuz etkilenmemesi ve sürekli iyileştirme çalışmalarının kaizen felsefesi 1şığında gerçekleştirilmesi gerekmektedir. Kalite artışının maliyet artırıcı değil, aksine maliyetlerin düşürülmesine hizmet eden bir gereklilik olduğu üzerinde durulmalıdır (Hacırüstemoğlu ve Şakrak, 2002:15). Kaizenin uygulanmasında maliyet, kalite ve iş güvenliği temel koşullar olarak karşımıza çıkmaktadır. Bunlardan bir tanesinden bile taviz verilmesi mümkün değildir. Örneğin kalite artarken maliyet de artıyorsa veya maliyet azalırken iş güvenliği de azalıyorsa kaizen gerçekleşmemiş demektir (Çetinay, 2013:12). Kalitenin durağan bir yönetim anlayışından ziyade dinamik bir yapıyı içinde barındırması nedeniyle kaizen felsefesiyle birlikte yürütülmesi, daha etkili sonuçların elde edilmesini sağlayacaktır. Bunun yanında toplam kalite yönetimi gibi kaizen felsefesinin de tam katılımı gerektirmesi, iki yöntemin uyumlu olduğunun göstergelerindendir (http://www.muhasebetr.com/yazarlarimiz/yilmazvelioglu/008/). Esasında kaizen maliyetleme, her mamul için daha düşük maliyete ulaşmanın yanında her maliyetleme yöntemiyle de uyumlu ve birlikte uygulanması gerekli bir tekniktir (Hacırüstemoğlu ve Şakrak, 2002:127).

Fabrika çalışanları ürünlere müşterinin değer kriterleri olan kalite, maliyet ve teslim süresi açısından bakarlar ve sürekli iyileştirme çabası içerisinde bulunurlarsa toplam kalitede önemli bir artış, fonksiyonlarda zenginleşme, maliyetlerde ve teslim sürelerinde önemli azalış mümkün olacaktır (Eskin vd., 2011:16). Kalitesi yüksek olan ürünlerin iadesi daha düşük olmakta, dolayısıyla garanti ve tamir maliyetleri de azalmakta, kusurlu mamullerin yeniden üretim sürecine sokulması sorunu ortadan kalkmakta ve verimlilik artışı sağlanmaktadır. Buradan hareketle kalite ile kârlılık arasında doğrudan bir ilişki olduğu da söylenebilir (Basık, 2012:359-360).

Kaizen maliyetlemenin genel olarak ulaşmak istediği sonuçlar; sürekli iyileştirme çalışmaları sayesinde toplam işlem süresini azaltmak, değer katmayan faaliyetleri ortadan kaldırmak, hatasız üretimi gerçekleştirmek, üretim maliyetlerini 
sürekli azaltmak, üretim süreçlerini basitleştirmek, fiili maliyet ile hedeflenen maliyet arasındaki farkı ortadan kaldırmak ve hedef kâr ile bütçelenen kâr arasındaki farkı azaltmaktır (Acar, 2005:71-72, Yükçü, 2000:32).

$\mathrm{Bu}$ amaçlara bakıldığında üretim süreçlerinin basitleştirilmesi, değer katmayan faaliyetlerin ortadan kaldırılması ve işlem süresinin azaltılması, başlı başına bir maliyet tasarrufuna imkan sağlayacaktır; çünkü fazladan gerçekleşen işlem süresi, fazladan işgücü ve enerji kullanılmasına neden olmaktadır. Hatasız üretimi gerçekleştiren işletmede hatalı ürünün yeniden işleme dâhil edilmesi, düzeltilmesi veya hurdaya ayrılmasına ilişkin maliyetlerin önüne geçilmektedir. Tüm bu iyileştirme unsurlarının sürekli hale getirilmesi, yani "iyileştirmenin standartlaştırılması", üretim maliyetlerinde azalmaya sebep olmakta, gerçekleşen maliyetlerle hedeflenen maliyetler arasındaki fark azalmakta ve dolayısıyla hedeflenen kâr düzeyine ulaşılmaktadır.

Buraya kadar yapılan açıklamaların ardından, şimdi de kalite ve kaizene yönelik iki çalışmanın sonuçları üzerinde durulmuştur. Kalite standartlarına ait belgelerin elde edilmesinden sonra bunun verimlilik üzerine etkilerinin incelendiği bir çalışmada aşağıdaki sonuçlar elde edilmiştir. Aşağıdaki tablo, ulaşılan sonuçların bir özeti niteliğindedir (Öz, 2006:330).

\begin{tabular}{|l|c|c|}
\hline & Azalma Olmuştur & Artı̧̧ Olmuştur \\
\hline Firmanın Yaptığı Yıllık Ciro & & Evet \\
\hline Firmanın Verimlilik Değeri & Evet & \\
\hline Artan Fire Miktarı & Evet & \\
\hline Üretilen Hatalı Ürün Miktarı & Evet & \\
\hline Üretim İçin Harcanan İş̧̧lik Süresi & & Evet \\
\hline Kapasite Kullanım Oranı & & Evet \\
\hline Toplam Kalite Kontrol Faaliyetleri & & Evet \\
\hline Proses Geliştirme ve AR-GE Süresi & & Evet \\
\hline Çalışılan Müşteri Sayısı & & Evet \\
\hline Müşteri Memnuniyeti Çalışmaları & & Evet \\
\hline Gelen Müşteri Şikayet Sayısı & Evet & \\
\hline Toplam Kalite Maliyetleri & & \\
\hline Periyodik ve Verimli Bakım & & \\
\hline
\end{tabular}

Yukarıdaki tablodan da görülebildiği gibi kalite belgesi elde edildikten sonra, yani işletme kaliteye yönelik çalışmalarını gerçekleştirdikten sonra yıllık ciro, verimlilik ve kapasite kullanım oranında artış elde ederken fire miktarı, hatalı ürün miktarı, işçilik süresi, müşteri şikayetleri ve toplam kalite maliyetlerinde azalma ortaya çıkmıştır.

Bir üretim işletmesinde uygulanan kaizen çalışmaları sonucunda ortaya çıkan tasarruf tutarları ve verimlilik artışlarının sunulduğu bir başka çalışmada ise aşağıdaki sonuçlar elde edilmiştir (Berber, 2013:88). 


\begin{tabular}{|l|l|}
\hline Gerçekleştirilen Kaizen & Yıllık Tasarruf Tutarı \\
\hline 5832 kg bor yağının israfı önlenmiş & 43.390 TL \\
\hline Talaş temizleme işleminin 50 dakikadan 16 dakikaya indirilmesi & 25.500 TL \\
\hline
\end{tabular}

Yukarıdaki tablodan da görülebileceği gibi daha az girdi ile aynı veya daha fazla çıktıyı elde etmeyi amaçlayan işletmelerin kaizen yönteminin tavsiyelerini uygulaması, küçük gibi görünen; ama toplamda oldukça yüksek tutarlara ulaşılabilecek tasarrufların ve verimlilik artışlarının elde edilmesine imkan sağlamaktadır.

\section{SONUÇ}

Günümüzün yoğun rekabet ortamında işletmelerin hem iç hem de dış paydaşları, ilişkili oldukları işletmenin sürekli daha kârlı ve piyasa değeri yükselen bir konuma sahip olmasını beklemektedirler. Dolayısıyla işletme yönetiminin bu beklentiler doğrultusunda hareket ederek söz konusu hususlarda oluşabilecek olumsuz durumların önüne geçmek için önlemler alması gerekmektedir. Bu kapsamda öncelikle üzerinde durulması gereken konu, maliyetleri yönetmektir. Maliyetleri yönetmek, maliyetlerin hesaplanmasından ibaret olmayıp maliyetlerde artışa sebep olan unsurların ve ürüne değer katmayan faaliyetlerin belirlenip ortadan kaldırılması da dahil olmak üzere çok yönlü bir çalışma sürecini gerektirmektedir.

Maliyetlerde düşüş sağlamayı amaçlayan işletmelerin tasarımdan itibaren faaliyetleri ve süreçleri dikkate alarak maliyet düşürmeyi sağlayacak firsatları iyi değerlendirmesi, önemsiz gibi düşünülen küçük hatalardan bile toplamda oldukça yüksek tutarlarda tasarruf elde edilebileceğinin farkına varılması gerekmektedir. Bu kapsamda küçük iyileştirmeleri benimseyen kaizen çalışmaları, işletmelere oldukça yararlı maliyet tasarruf tavsiyelerinde bulunmaktadır. Dolayısıyla daha az girdi kullanımıyla daha fazla çıktı elde edilmesine, yani verimliliğe katkı sağlamaktadır. Bunun yanında kaliteli üretim süreçleri oluşturarak kalitesizliğin maliyetlerinden kaçınan ve kaliteli mamuller üreterek hatalı ürünlerin iadesi gibi problemlerden kurtulan işletmeler, aynı girdilerle kaliteli ve hatasız çıktılar elde edecektir.

\section{KAYNAKÇA}

ACAR, D. (2005). Küresel Rekabette Maliyet Yönetimi ve Yaklaşımları: Tekstil Sektörü ile İlgili Bir Araştırma. Asil Yayın Dağıım, 1. Bask1, Ankara.

AKGÜN, M. (2005). "Kalite Maliyetlerinin Faaliyet Tabanlı Maliyetleme Sistemine Entegrasyonu”. Muhasebe ve Denetime Bakış, May1s: 31-48.

ALKAN, H. (2001). "İşletme Başarısında Maliyet Yönetiminin Rolü ve Maliyet Yönetiminde Yeni Yaklaşımlar". Süleyman Demirel Üniversitesi Orman Fakültesi Dergisi, A(2): 177-192.

ALTINOK, M. \& SAÇLI, C., (2009). "Toplam Kalite Yönetiminin Verimliliğe Etkisi-Panel Mobilya Üreten Bir İşletmede Çerçeve Uygulama”. SÜ İ̈BF Sosyal ve Ekonomik Araştırmalar Dergisi, 18: 63-86.

BASIK, F. O. (2012). "Rekabet Stratejisinde Maliyet Yönetimi”. Türkmen Kitabevi, İstanbul.

BERBER, İ. (2013). "Yalın Üretim Teknikleri, Kaizen ve Sektörel Uygulamaları". Mustafa Kemal Üniversitesi Fen Bilimleri Enstitüsü Yayımlanmamış Yüksek Lisans Tezi, Hatay.

ÇETiNAY, H. (2013). "Kaizen El Kitabı - Sürekli İyileştirme". Treem Kaizen El Kitabı, Treem Eğitim Danışmanlık, http://www.treem.com.tr/kaizenelkitabi.pdf, Erişim: 20.09.2016.

ESKIN, M., TİRYAKİOĞLU, U. \& YÜCEILL, H. D. (2011). "Sanayide Sürekli Gelişme için: "Kaizen”. İstanbul Sanayi Odası, İkinci Bask1, İstanbul.

GEÇİKLİ, F. (1999). "Sürekli İyileştirme (Kaizen) ve Sürekli İyileştirme İçinde Yönetimin Yeri”. Celal Bayar Üniversitesi İIBF Yönetim ve Ekonomi Dergisi, 5: 225-239. 
HACIRÜSTEMOĞLU, R. \& ŞAKRAK, M. (2002): “Maliyet Muhasebesinde Güncel Yaklaşımlar”. Türkmen Kitabevi, İstanbul.

KARAKAYA, M. (2004). "Maliyet Muhasebesi”. Gazi Kitabevi, Ankara.

KARCIOĞLU, R. (2001). “Toplam Kalite Yönetiminde Faaliyete Dayalı Maliyetleme Yönteminin Kullanılması”, Muhasebe ve Denetime Bakış, Ocak: 9-18.

KAYA, C. T. (2013). "Hedef Maliyetleme Sistemiyle Kaizen ve Yaşam Çevrim Maliyetleri Arasındaki Çapraz İlişkiler". MÖDAV, 2013/4: 135-154.

KUTLU, H. A. (2008). "Kalite Maliyetleri ve Yaşam Boyu Maliyetleme Yöntemi”. Muhasebe ve Denetime Bakış, Ekim: 85-101.

MACPHERSON, W., LOCKHART, J. \& KAVAN, H. (2015). "Kaizen: a Japanese Philosophy and System for Business Excellence". Journal of Business Strategy, September, 36(5): 3-9.

MONDEN, Y. \& HAMADA, K. (1991). "Target Costing and Kaizen Costing in Japanese Automobile Companies". Journal of Management Accounting Research, Fall: 16-34.

ÖZ, İ. (2006). "Kalite ve Sistem Belgelerinin, Etkinlik ve Verimlilik Üzerindeki Etkilerinin Analizi - Otomotiv Sektöründe Bir Uygulama”. İstanbul Üniversitesi Sosyal Bilimler Enstitüsü Yayımlanmamış Yayımlanmamış Yüksek Lisans Tezi, İstanbul.

ÖZBİRECIKLİ, M. (2001). “Kalite Maliyetlerinin Muhasebe Sistemindeki Yeri ve Yönetsel Kararlara Etkileri”. Muhasebe ve Denetime Bakış, Mayıs: 82.

VELIOĞLU, Y. (2012). "Maliyet-Verimlilik-Kalite Yönetiminde Modern $\quad$ Yaklaşım: Kaizen Felsefesi”. http://www.muhasebetr.com/yazarlarimiz/yilmazvelioglu/008/, Erişim: 12.10.2016.

YÜKÇÜ, S. (2000). “Maliyet Düşürmede Sistematik Yaklaşımlar”, Muhasebe ve Denetime Bakış, Ekim: 23-42. 